\title{
Microbiology, Sensory Evaluation and Shelf Life of Irradiated Chicken Breast Fillets Stored in Air or Vacuum
}

\author{
Samira Pirola Santos Mantilla ${ }^{1 *}$, Érica Barbosa Santos ${ }^{1}$, Helio de Carvalho Vital ${ }^{2}$, Sérgio \\ Borges Mano ${ }^{1}$, Mônica Queiroz de Freitas ${ }^{1}$ and Robson Maia Franco ${ }^{1}$ \\ ${ }^{I}$ Departamento de Tecnologia de Alimentos; Faculdade de Veterinária; Universidade Federal Fluminense; Rua \\ Vital Brazil, 64; Niterói - RJ - Brasil. ${ }^{2}$ Centro Tecnológico do Exército; Av. das Américas, 28705; 23020-470; Rio \\ de Janeiro - RJ - Brasil
}

\begin{abstract}
This work investigated the effects of different packaging methods (air and vacuum) combined with irradiation (0.0, 2.0 and $3.0 \mathrm{kGy}$ ) on the preservation of chicken breast fillets stored at $1^{\circ} \mathrm{C}$ for up to 18 days by sensorial test, determination of $\mathrm{pH}$ and bacterial growth. The findings indicated that the post-irradiation lag phase increased with the dose, leading to an extension in shelf-life. Vacuum-packed samples irradiated at $3.0 \mathrm{kGy}$ exhibited the longest shelf life. Among the analyzed bacteria, coliforms and Listeria spp. were most sensitive to gamma radiation. All the fillets acquired more attractive coloration and better overall impression with irradiation. The combined use of vacuum packaging and irradiation $(3.0 \mathrm{kGy})$ reduced the microbial populations without causing change in $\mathrm{pH}$ and yielded a significant shelf-life extension of refrigerated fillets, besides improving its appearance.
\end{abstract}

Key words: Irradiation, chicken fillets, modified atmosphere, microbiology, sensory tests

\section{INTRODUCTION}

Between 2000 and 2008, the most rapid expansion, with an annual growth rate of more than six per cent a year, occurred in South America. Over three-quarters of this expansion was attributed to the growth in the industries in Brazil, where poultry meat output escalated by almost $75 \%$, from $6.1 \mathrm{mt}$ to $10.7 \mathrm{mt}$ between 2000 and 2008 (The Poultry Site, 2010).

Poultry meat is a nutritious food and it is consumed all over the world because of its relatively low cost and low fat content. However, it is highly perishable with a relatively short shelf life even when it is kept under refrigeration. Thus, developing more appropriate technologies for its preservation could be highly useful. In order to increase the shelf life of meat products, vacuumpackaging has been used although it has not been able to extend the shelf life of the packaged product for a long time. The gamma irradiation has been used in combination with packaging in modified atmosphere in order to improve the safety and further enhance the shelf-life extension of meat.

The safety and efficiency of irradiation in food preservation has been thoroughly demonstrated worldwide (Pelczar et. al., 1997). The doses of 1.5 and $3.0 \mathrm{kGy}$ for the treatment of refrigerated and frozen chicken meat, respectively, were authorized in the USA in 1992 (Lee, 1995). The Brazilian legislation for food irradiation has been regarded

*Author for correspondence: samiramantilla@yahoo.com.br 
as one of the most advanced ones in the world, allowing the treatment of any kind of food (Vital and Freire Jr., 2008). However, the use of such technology in Brazil is still mostly limited to the treatment of spices, animal feed and other food products to be exported. However, there has been an increasing joint effort geared at informing the population on the principles, safety and benefits of treating foods with ionizing radiation (Hernandez et al., 2003).

Bacteria tend to be more resistant to radiation during the latency (lag phase), becoming more sensitive as they enter the logarithmic growth phase and reach the lowest resistance at its end (Jay, 2005). Gram-negative (pathogenic and spoilage) bacteria are generally more sensitive than the Gram-positive vegetative cells (Franco and Landgraf, 1996).

The combination of different methods of food preservation should be seen as an alternative in the food industry, for example, the use of vacuumpacked, gamma radiation and refrigeration. However, in order to ensure that the combined use of those techniques does not produce changes in the original characteristics of the products, testing of sensory acceptance must be performed.

The objective of this study was to determine the effectiveness of the combined treatment of gamma irradiation $(0,2.0$ and $3.0 \mathrm{kGy})$ and air or vacuum packaging for the preservation of refrigerated chicken fillets by monitoring the microbial growth parameters in order to determine the shelf-life extension, variation of $\mathrm{pH}$ and sensory acceptance.

\section{MATERIALS AND METHODS}

The experiments were performed in two phases. During the first day of phase one (day zero), $2 \mathrm{~kg}$ of refrigerated chicken breast fillets were purchased from a market in Niterói, RJ and transported in boxes of expanded polystyrene filled with ice to the Laboratory, where all the bacteriological analyses and determination of $\mathrm{pH}$ were performed starting from day zero. Following analysis were made: counting of heterotrophic aerobic mesophilic (HAM), counting of bacteria of the genera Listeria, Yersinia and Aeromonas, and enumeration of total and thermotolerant coliforms. Each fillet was aseptically divided in 14 pieces with $18 \mathrm{~g}$ and each of those samples was packed in a plastic bag having a multilayered structure with low permeability to gases. Two different packing atmospheres were tested in two sets, including 10 samples each: 1) air-packed (control) and 2) vacuum-packed. A sample from each treatment was analyzed individually after $1,3,5,7,9,12$ or 18 days of storage at $1^{\circ} \mathrm{C} \pm 1{ }^{\circ} \mathrm{C}$.

The following growth media were used: plate count agar (PCA; Merck) for HAMB and PAHB, Oxford Listeria Base (Himedia) with Listeria Selective Supplement (Oxford Formulation; Oxoid) (SR0140) for Listeria spp., Mac Conkey Agar with Yersinia Selective Supplement (SR109; Oxoid) for Yersinia spp., Starch-ampicillin Agar (SA; Himedia) enriched with $1 \%$ ampicilin for Aeromonas spp., and Fluorocult broth for enumeration of total and thermotolerant coliforms. Merck`s miniaturized methodology (2000), as modified by Franco and Mantilla (2004), was used for coliform enumeration. It consisted of employing automatic pippetors connected to sterilized pointers for preparation and inoculation of $0.1 \mathrm{~mL}(100 \mu \mathrm{L})$ from different dilutions into 1 $\mathrm{mL}(1000 \mu \mathrm{L})$ of Fluorocult selective broth.

In the second phase of experiments, fillets were obtained in the same conditions as in phase 1, out of $4 \mathrm{~kg}$ of fresh chicken breast; however, different doses of radiation and packing atmospheres were tested yielding four sets of samples: 1) air-packed, irradiated with $2.0 \mathrm{kGy}$; 2) vacuum-packed, irradiated with $2.0 \mathrm{kGy} ; 3$ ) air-packed, irradiated with $3.0 \mathrm{kGy}$ and 4) vacuum-packed, irradiated with $3.0 \mathrm{kGy}$. The analyses performed were the same as those in phase 1.

Since the bacterial populations in the beginning of the two phases were different, normalization of the initial reading of each phase was applied to all data of the corresponding phase so that the bacterial growth during both the phases could be compared and described according to the modified Gompertz`s equation (Gibson et al., 1987) by using a special computer program (Baranyi and Roberts, 1994).

The sensory evaluation was performed in the form of an acceptance test, where samples from different treatments were randomly subjected to judgment by 33 untrained panelists. Color and overall impression were judged according to a hedonic nine-point scale (Stone and Sidel, 1998), where, 9 corresponded to "disliked extremely" and 1 to "liked extremely". Scores from 1-5 were considered acceptable. Differences between the variables were tested for significance by one-way ANOVA with Tukey's post test using SAS 
program. Differences at $p<0.05$ were considered to be significant.

\section{RESULTS AND DISCUSSION}

The findings indicated that the post-irradiation lag phase increased with dose, leading to an extension in shelf life. Similar results were also found by Spoto et al. (2000), who concluded that irradiation could efficiently be used in the preservation of chicken meat.

\section{Shelf-life extension}

The samples found to exhibit the longest shelf life were those vacuum-packed and irradiated with 3.0 $\mathrm{kGy}$, followed by the air-packed ones also treated with $3.0 \mathrm{kGy}$ (Table 1). Then came the samples exposed to $2.0 \mathrm{kGy}$ (air- and vacuum-packed), followed by the unirradiated samples, first the vacuum-packed and finally the air-packed ones. As expected, a larger decrease in the population of bacteria was found in the samples irradiated with $3.0 \mathrm{kGy}$, consequently leading to a larger extension in the shelf life. Vacuum packaging combined with irradiation at $3.0 \mathrm{kGy}$ resulted in extending the shelf life to 12 days, which was more than double in comparison with the unirradiated air-packed samples that remained good for five days only. These findings were consistent with those obtained by Abu-Tarboush et al. (1997) who reported that irradiation of refrigerated chicken meat with $2.5 \mathrm{kGy}$ led to a 12-day shelf life.Similar results were observed by Grandison and Jennings (1993), who reported that air-packed unirradiated samples of ground chicken meat deteriorated in two days of storage, while the treatment with $3.1 \mathrm{kGy}$ significantly increased the shelf life of the samples. Chouliara et al. (2008) also found an extension in the shelf life of fresh poultry meat treated with 2.0 and 4.0 Gy. They reported that the total counts of bacteria in the unirradiated air-packed samples reached the microbiological limit on the $5-6^{\text {th }}$ day of storage at $4^{\circ} \mathrm{C}$, whereas those irradiated with $2.0 \mathrm{kGy}$ reached such level on the $15^{\text {th }}$ day, and those irradiated with $4.0 \mathrm{kGy}$ only after 22-23 days of storage. Miyagusku et al. (2003) observed that the samples of refrigerated chicken breast vacuumpacked and irradiated at $3.0 \mathrm{kGy}$ did not reach 7.0 $\log \mathrm{CFU} / \mathrm{g}$ until the $30^{\text {th }}$ day of storage, remaining with scores of up to 5.0 Log CFU/g.

Table 1 - Shelf-life and growth parameters of bacteria found in vacuum- and air-packed chicken breast fillets treated with 0,2 and $3.0 \mathrm{kGy}$ and stored for 18 days at $1^{\circ} \mathrm{C}$.

\begin{tabular}{|c|c|c|c|c|c|c|c|}
\hline \multirow{2}{*}{$\begin{array}{c}\text { Treatment } \\
\text { (Packing/(Dose) }\end{array}$} & \multirow{2}{*}{$\begin{array}{c}\text { Shelf Life (days) } \\
\text { Based on } \\
\text { Limit: } 10^{7} \text { CFU/g }\end{array}$} & $\begin{array}{c}\text { Bacterial Growth } \\
\text { Parameters }\end{array}$ & Me & CT & CTer & Lis & Aero \\
\hline & & \multicolumn{6}{|c|}{ Initial count normalized to 1.0 log cycle } \\
\hline \multirow{3}{*}{ Air / 0 kGy } & \multirow{3}{*}{5} & g (days) & 0.6 & 0.4 & 1.1 & 0.5 & - \\
\hline & & Lag (days) & 1.9 & 2.4 & 8.9 & 1.4 & - \\
\hline & & $\mathrm{CF}(\log \mathrm{CFU} / \mathrm{g})$ & 4 & 2.2 & 1.7 & 5 & nd \\
\hline \multirow{3}{*}{ Vacuum / 0 kGy } & \multirow{3}{*}{7} & g (days) & 0.7 & 0.7 & - & 0.2 & - \\
\hline & & Lag (days) & 3.8 & 2.8 & - & 4.2 & - \\
\hline & & $\mathrm{CF}(\log \mathrm{CFU} / \mathrm{g})$ & 3.8 & 3 & nd & 4.5 & nd \\
\hline \multirow{3}{*}{ Air / 2.0 kGy } & \multirow{3}{*}{9} & g (days) & 0.7 & 18.7 & - & - & - \\
\hline & & Lag (days) & 5 & - & - & - & 7.7 \\
\hline & & $\mathrm{CF}(\log \mathrm{CFU} / \mathrm{g})$ & 3.3 & 0.6 & nd & nd & 0.8 \\
\hline \multirow{3}{*}{ Vacuum / 2.0 kGy } & \multirow{3}{*}{9} & g (days) & 1 & 1.7 & - & - & 0.8 \\
\hline & & Lag (days) & 4.4 & 6.9 & - & - & 7.7 \\
\hline & & $\mathrm{CF}(\log \mathrm{CFU} / \mathrm{g})$ & 2.7 & 0.5 & nd & nd & 0.7 \\
\hline \multirow{3}{*}{ Air / 3.0 kGy } & \multirow{3}{*}{10.5} & g (days) & 0.4 & - & - & - & 0.3 \\
\hline & & Lag (days) & 5.8 & - & - & - & 7.7 \\
\hline & & CF $(\log \mathrm{CFU} / \mathrm{g})$ & 1.7 & nd & nd & nd & 3.3 \\
\hline \multirow{3}{*}{ Vacuum / 3.0 kGy } & \multirow{3}{*}{12} & g (days) & 0.7 & - & - & - & 1.7 \\
\hline & & Lag (days) & 5.9 & - & - & - & 12 \\
\hline & & $\mathrm{CF}(\log \mathrm{CFU} / \mathrm{g})$ & 1.6 & nd & nd & nd & 0.7 \\
\hline
\end{tabular}




\section{Heterotrophic aerobic mesophilic bacteria}

Irradiation with $3.0 \mathrm{kGy}$ reduced the number of aerobic mesophilic bacteria in the air-packed samples by approximately $2 \log$ cycles (Fig. $1 \mathrm{~A}$ ), while a much smaller drop (0.81 log cycle) was found for the vacuum-packed fillets treated with the same dose. Lescano (1991) also found that the irradiation of chicken breast with $2.5 \mathrm{kGy}$ reduced the total bacterial count by approximately $2 \log$ cycles. Thayer et al. (1995) found that the total bacterial count of chicken wings was reduced by about $2 \log$ cycles with irradiation at $1.4 \mathrm{kGy}$.

In the present experiment, the doubling time was higher in vacuum-packed than in air-packaged samples, hinting that the mesophilic bacteria were not able to start the growth in vacuum as they grew more easily in air. This was in agreement with the results of bacterial count at the end of storage, when the vacuum-packaged samples had lower bacterial count. The highest bacterial growth in chicken breast wrapped in air when compared with the vacuum-packed ones was also found by Jiménez et al. (1997). They reported a rapid growth of viable bacteria in air-packed samples, reaching a population of $8 \log \mathrm{CFU} / \mathrm{g}$ after four to five days of storage at $4^{\circ} \mathrm{C}$; the use of vacuum packaging extended the time required for the total count of bacteria to reach $8 \log \mathrm{CFU} / \mathrm{g}$ to two or three days of storage.

In this work, shelf-life extension was mostly due to the irradiation-induced prolongation of the lag phase, found to be higher for the samples treated with $3.0 \mathrm{kGy}$.

\section{Coliforms}

The thermotolerant coliforms were unable to grow in the samples packed in vacuum and in irradiated ones, and were detected only in the unirradiated fillets packed in air. Miyagusku et al. (2003) detected E. coli in the control samples only and no significant counts were found during the storage in the irradiated samples.

The total coliform group did not show detectable growth in the samples irradiated at $3.0 \mathrm{kGy}$ (Fig. 1 C) and showed a longer lag phase in the vacuumpackaged samples treated with $2.0 \mathrm{kGy}$. According to the data that group was eliminated from the chicken fillets irradiated to $3.0 \mathrm{kGy}$, and had difficulty to start growth after irradiation with 2.0 kGy. Abu-Tarboush et al. (1997) also found that irradiation with $2.5 \mathrm{kGy}$ and storage at $4^{\circ} \mathrm{C}$ for 21 days was sufficient to eliminate total coliforms in chicken meat. In another experiment, gamma irradiation of chicken with 1 and $1.8 \mathrm{kGy}$ was sufficient to eliminate total coliforms (Lewis et al., 2002).

\section{Other bacteria}

Listeria spp. was only detected in the control samples packed in air and vacuum, being eliminated with irradiation at 2.0 and $3.0 \mathrm{kGy}$ (Fig. 1 D). Roberts and Weese (1995) reported that irradiation of meat with a dose up to $3.0 \mathrm{kGy}$ effectively eliminated over $99 \% \quad L$. monocytogenes. Samelis et al. (2005) reported that 4.0 kGy completely eliminated Listeria spp. frozen meat. Trivedi et al. (2007), also observed that irradiation with $3.0 \mathrm{kGy}$ was effective in eliminating $10^{2} \mathrm{CFU} / \mathrm{g}$ of $L$. monocytogenes inoculated on diced chicken meat and turkey frankfurters.

Aeromonas spp. was not detected in control samples. Kumar et al. (2000) isolated Aeromonas spp. in 33 (13.41\%) of 246 food samples of animal origin. In the present study, this genus was only detected in air- and vacuum-packed samples irradiated with 2.0 and $3.0 \mathrm{kGy}$ (Fig. $1 \mathrm{~B}$ ). A possible explanation for this could be that such bacterium hardly grew in media where it had to face competition with other microorganisms, as it was the case at the beginning of the experiment. Thus, when the microbiota was reduced by irradiation, Aeromonas spp. was able to develop. However, Thayer (1995) observed that doses below $3.0 \mathrm{kGy}$ were sufficient to eliminate Aeromonas hidrophila in chicken meat.

Yersinia spp. was not detected in any sample from the beginning. According to Jay (2005), the pig is the most common source of this pathogen. In a pilot investigation, performed in Novi Sad, Trajković-Pavlović et al. (2007) did not find Yersinia enterocolitica in any of the tested samples (90 of fresh meat and 167 of ready-to-eat food). Bucher et al. (2008) examined the prevalence of pathogenic $Y$. enterocolitica in the animals and foodstuffs in Bavaria and reported it only from raw pork, especially from the edible offal. Some raw pork sausages and only one poultry sample were PCR positive. 

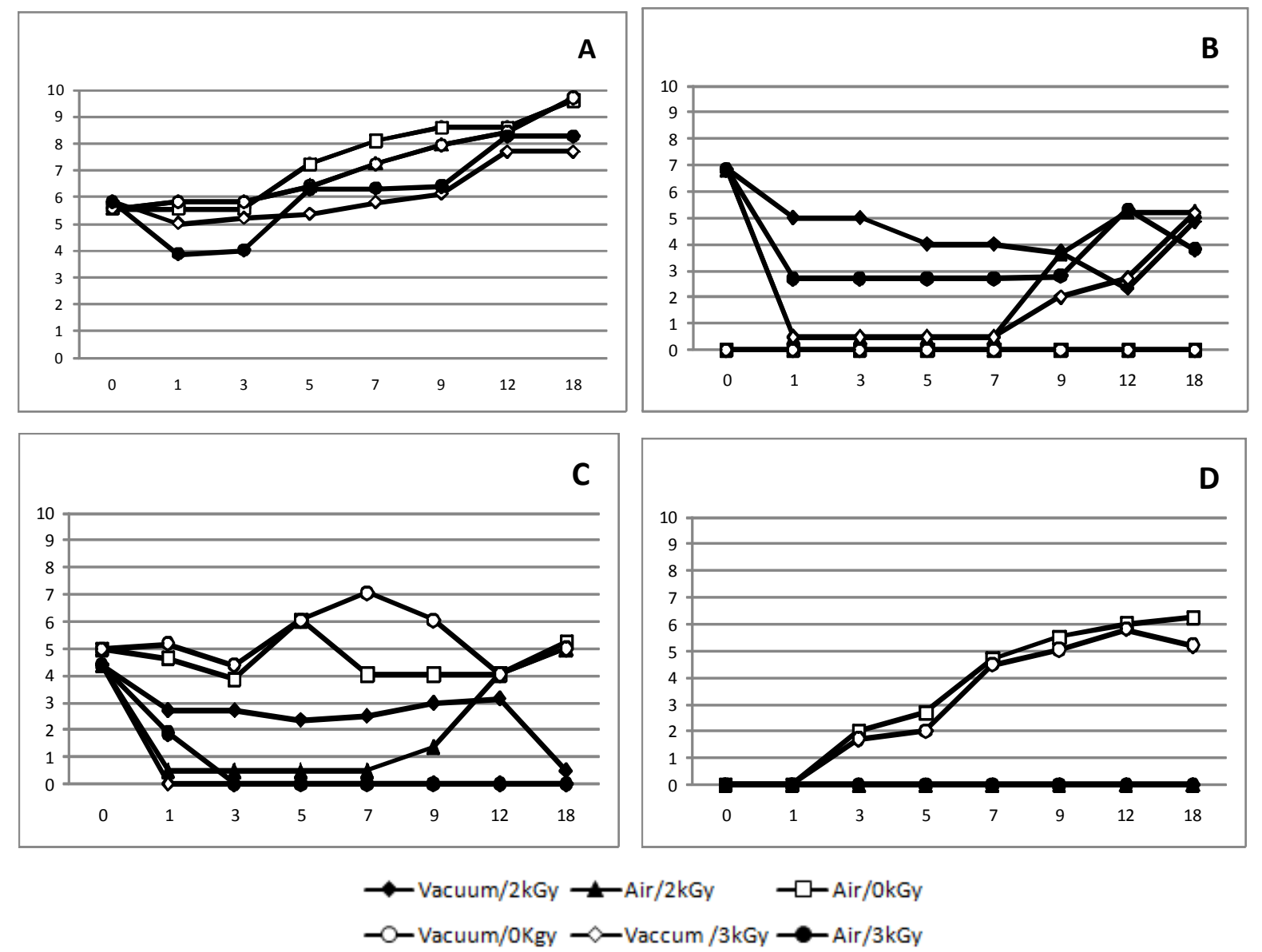

Figure 1 - Growth bacterial curves (Log CFU/g X Days of Storage) in samples of refrigerated chicken breast fillets subjected to six different treatments. (A)- Heterotrophic aerobic mesophilic bacteria; (B)- Aeromonas spp.; (C)- Total coliforms and (D)- Listeria spp.

\section{pH values}

There were no changes in $\mathrm{pH}$ at the beginning of the experiment. As expected, the vacuum-packed samples consistently showed a lower $\mathrm{pH}$ value, due to the predominance of acid-producing bacteria. Samples packaged in the air showed an increase in $\mathrm{pH}$ during the storage in the same way as reported by Miyagusku (2008), which could be attributed to the faster growth of spoilage bacteria. The $\mathrm{pH}$ of air-packed irradiated and unirradiated samples ranged from 5.6 to 7.0 and 5.4 to 6.0 , respectively (Fig. 2), confirming the data obtained by Pinto et al. (2005) who found that the samples of unirradiated chicken breast wrapped in air had a change in $\mathrm{pH}$ from 5.9 to 6.5 and the irradiated samples had $\mathrm{pH}$ ranging between 5.9 and 6.8, also informing that irradiation provided no changes in $\mathrm{pH}$ values compared with the control samples.

\section{Sensory acceptance}

Table 2 showed that the judges preferred the airpacked samples irradiated with 2.0, although no significant difference was obtained relatively to the vacuum-packed samples irradiated with $3.0 \mathrm{kGy}$. All the irradiated fillets showed a color more attractive than non-irradiated. Lewis et al. (2002) concluded that irradiation at $1.0 \mathrm{kGy}$ improved the color of chicken breast fillets. Nanke et al. (1998) also observed changes in the color of pork and turkey irradiated at doses of $1.5 \mathrm{kGy}, 3.0$ kGy, 4.5 kGy, 7.5 kGy and $10.5 \mathrm{kGy}$, which showed up red due to irradiation. Nam and Ahn (2002) found that Comioglobina was responsible for the pink color of chicken meat caused by the interaction with carbon monoxide during irradiation. Kim et al. (2002) also found that the development of red color in irradiated meat was 
due to the production of gas, especially $\mathrm{CO}$. Similar results were found by Millar et al. (1995), who reported higher redness in the chicken breast irradiated at $5.0 \mathrm{kGy}$ compared with unirradiated controls. Those authors concluded that ionizing radiation was able to change the coloration of poultry meat depending on the kind of muscle type and properties of the skin.

However, Kanatt et al. (1997) did not find any change in sensory attributes such as appearance, color and odor after irradiating the chicken with $2.5 \mathrm{kGy}$. Similar reports were discussed by Souza et al. (2007) who investigated the influence of radiation on the levels of iron and color of pigments of thighs and chicken breast meat irradiated at doses 0,1 and $2.0 \mathrm{kGy}$ and found that the color was not influenced by those doses. The lack of changes in sensory properties of the chicken meat was probably due to the low doses (below $3.0 \mathrm{kGy}$ ) used by these researchers.

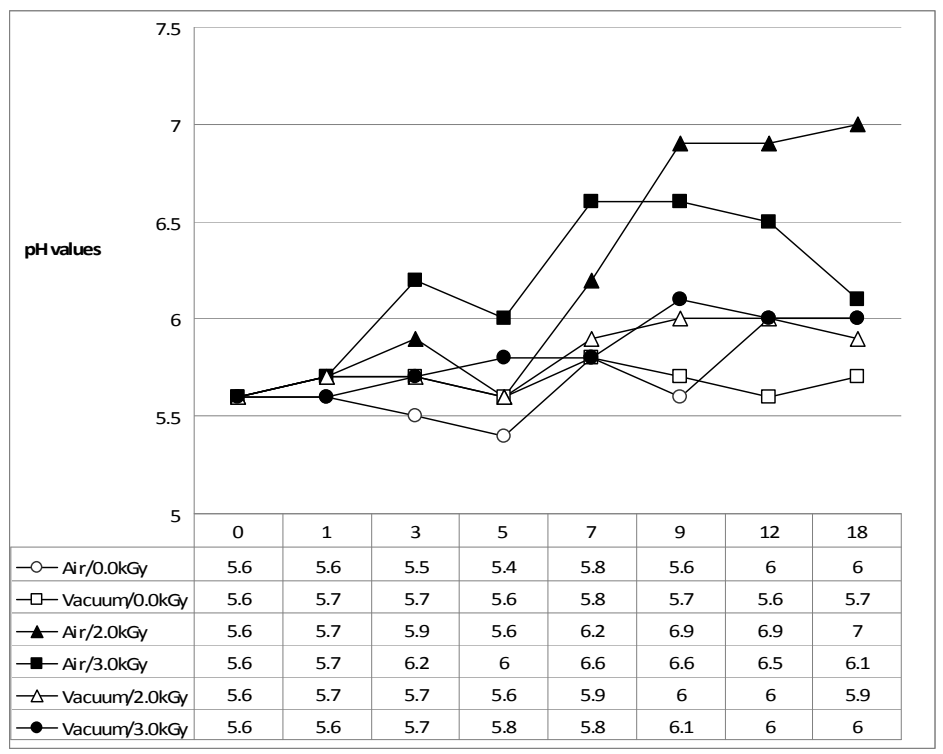

Figure 2- $\mathrm{pH}$ values for all treatments during the experiment.

Table 2 - Results from Tukey`s Test for the color of chicken fillets subjected to different treatments.

\begin{tabular}{ll}
\hline Treatment & Mean \\
\hline Vaccum/0.0 kGy & $5.0^{\mathrm{a}}$ \\
Air/0.0 kGy & $4.7^{\mathrm{ab}}$ \\
Air/ $3.0 \mathrm{kGy}$ & $3.97^{\mathrm{b}}$ \\
Vacuum/2.0 kGy & $3.67^{\mathrm{bc}}$ \\
Vacuum/3.0 kGy & $3.42^{\mathrm{c}}$ \\
Air/2.0 kGy & $3.36^{\mathrm{c}}$ \\
\hline
\end{tabular}

*Means followed by at least one letter the same, in the same column do not differ ( $p>0.05)$.

In relation to sensory acceptability of the chicken fillets to the overall impression (Table 3), it was found that only the vacuum-packed ones were rejected by the judges, probably due to the change from the original meat format. The treatment that received the highest scores in that attribute was air packaging combined with irradiation with 2.0 $\mathrm{kGy}$. It was followed by vacuum packaging treated with $3.0 \mathrm{kGy}$, then with $2.0 \mathrm{kGy}$, followed by air packaging irradiated with $3.0 \mathrm{kGy}$ and finally the unirradiated sample packed in air. In this work, irradiation with 2.0 and $3.0 \mathrm{kGy}$ improved the overall appearance of the samples. Hashim et al. (1995) also reported that irradiation did not affect the appearance (humidity and brightness) of breast and thigh chicken refrigerated raw chicken. AbuTarboush et al. (1997) observed that irradiation of chicken meat $(2.5,5.0,5.7$ and $10.0 \mathrm{kGy})$ caused minor changes in product acceptance in relation to appearance, aroma, texture and flavor. 
Table 3 - Results from Tukey`s Test for the overall impression of chicken fillets subjected to different treatments.

\begin{tabular}{ll}
\hline Treatment & Mean \\
\hline Vaccum/0.0 kGy & $5.76^{\mathrm{a}}$ \\
Air/0.0 kGy & $4.81^{\mathrm{ab}}$ \\
Air/3.0 kGy & $4.63^{\mathrm{abc}}$ \\
Vacuum/2.0 kGy & $4.57^{\mathrm{abc}}$ \\
Vacuum/3.0 kGy & $4.51^{\mathrm{abc}}$ \\
Air/2.0 kGy & $3.67^{\mathrm{c}}$ \\
\hline
\end{tabular}

*Means followed by at least one letter the same, in the same column do not differ ( $\mathrm{p}>0.05)$.

\section{CONCLUSION}

Based on the results obtained in this work, it could be concluded that irradiation at doses of 2.0 and $3.0 \mathrm{kGy}$ significantly increased the shelf life of refrigerated chicken meat in comparison with the unirradiated air-packed samples. Irradiation of the samples under vacuum was more efficient in extending the shelf life and gave chicken fillets with color and overall more desirable to the consumers. Thermotolerant coliforms and Listeria spp. were eliminated with irradiation, whereas Aeromonas spp. was able to develop in the irradiated samples. The $\mathrm{pH}$ of the samples did not show large variations during the storage period. Irradiation improved the color of the fillets and maintained a overall good impression of the product. Results also demonstrated that the combined effect of vacuum-packed and irradiation (3.0 kGy) was able to extend the shelf life of refrigerated chicken fillets and control deteriorating and pathogenic microbiota, making them safer and more attractive to the consumers.

\section{ACKNOWLEDGMENTS}

The authors gratefully acknowledge the CAPES for financial support for this study and the Nuclear Defense Section of CTEx for performing all the irradiations.

\section{REFERENCES}

Abu-Tarboush, H.M.; Al-Kahtani, H. A.; Atia, M.; Abou-Arab, A.A.; Bajaber, A.S.; El-Mojaddidi, M.A. (1997), Sensory and microbial quality of chicken as affected by irradiation and postirradiation storage at $4{ }^{\circ}$ C. J. Food Prot, 60, 761-770.

Baranyi, J.; Roberts, T.A. (1994), A dynamic to predicting bacterial growth in food. Int $J$ Food Microbiol., 23, 277-294.
Bucher, M.; Meyer, C.; Grötzbach, B.; Wacheck, S.; Stolle, A.; Fredriksson-Ahomaa, M. (2008), Foodborne Pathogens and Disease. Foodborne Pathogens and Disease, 5 (3): 273-280.

Chouliara, E.; Badeka, A.; Savvaidis, L.; Kontominas, M. G. (2008), Combined effect of irradiation and modified atmosphere packaging on shelf-life extension of chicken breast meat: microbiological, chemical and sensory changes. Journal European Food Research and Technology, 226 (4), 877-888.

Franco, B. D. G. M.; Landgraf, M. (1996), Microrganismos Patogênicos de Importância em Alimentos. In- Microbiologia dos Alimentos. ed. Atheneu, São Paulo, pp. 33-82.

Franco, R. M.; Mantilla, S. P. M. (2004), Escherichia coli em corte de carne bovina: avaliação da metodologia aplicada e sensibilidade antimicrobiana dos sorovares predominantes. Paper presented at $14^{\text {th }}$ Seminário de Iniciação Científica e Prêmio UFF Vasconcellos Torres de Ciência e Tecnologia, Niterói-RJ, Brazil.

Gibson, A.M.; Bratchell, N.; Roberts, T.A. (1987), The effect of sodium chloride and temperature on the rate and extent of growth of Clostridium botulinum type A in pasteurized pork slurry. J Appl. Bacteriol, 62, 479490.

Grandison, A.; Jennings, A. (1993), Extension of the shelf life of fresh minced chicken meat by electron beam irradiation combined with modified atmosphere packaging. Food Control, 4, (2), 83-88.

Hashim, I. B.; Resurreccion A, V. A.; Mcwatters, K. H. (1995), Descriptive sensory analysis of irradiated frozen or refrigerated chicken. J Food Sci, 60 (4), 664-666.

Hernandes, N. K.; Vital, H. C.; Sabaa Srur, A. U. O. (2003), Irradiação de alimentos: vantagens e limitações. Boletim SBCTA, 37 (2), 154-159.

Jay, J. M. (2005), Microbiologia de alimentos. 6 ed. 711 pp. ed. Artmed, Porto Alegre.

Jiménez, S.M.; Salsi, M.S.; Tiburzi, M.C.; Rafaghelli, R.C.; Tessi M.A; Coutaz, V.R. (1997), Spoilage microflora in fresh chicken breast stored at $4{ }^{\circ} \mathrm{C}$ : influence of packaging methods. J Appl Microbiol, 83 (5), $613-618$. 
Kanatt, S. R.; Paul, P.; D' Souza, S. F; Thomas, P. (1997), Effect of gamma irradiation on the lipid peroxidation in chicken, lamb and buffalo meat during chilled storage. J Food Safety, 17, 283-294.

Kim, Y. H.; Nam, K. C.; Ahn, D. U. (2002), Color, Oxidation-Reduction Potential, and Gas Production of Irradiated Meats from Different Animal Species. $J$ Food Sci, 67 (5), 257-265.

Kumar, A.; Bachhil, V. N.; Bhilegaonakar, K. N.; Agarwal, R. K.. (2000), Occurrence of enterotoxigenic Aeromonas species in foods. $J$ Comminicable Dis, 32 (3), 169-174.

Lee, M.; Sebranek, J. G.; Olson, D. G.; Dickson, J. S. (1995), Irradiation and Packaging of Fresh Meat and Poultry. J Food Prot, 59 (1), 62-72.

Lescano G.; Narvaiz P.; Kairiyama E.; Kaupert N. (1991), Effect of chicken breast irradiation on microbiological, chemical and organoleptic quality. Lebensmittel - Wissenschaft Technologie, 24 (2), 130134.

Lewis, S. J.; Vela'Squez, A.; Cuppett, S. L.; Mckee, S. R. (2002), Effect of Electron Beam Irradiation on Poultry Meat Safety and Quality. Poult Sci, 81, 896903.

Merck (2000), Microbiology Manual. 407 pp. Berlin. Germany.

Millar, S. J.; Moss, B. W.; Macdougall, D. B.; Stevenson, M. H. (1995), The effect of ionizing radiation on the CIELAB color coordinates of chicken breast meat as measured by different instruments. Int J Food Sci Tech, 30, 663-674.

Miyagusku, L.; Chen, F.; Leitão, M. F. de F.; Baffa, O. (2003), Avaliação microbiológica e sensorial da vida útil de cortes de peito de frango irradiados. Cienc Tecnol Alimentos, 23, 7-16.

Miyagusku, L. (2008), Influência da radiação ionizante $\left({ }^{60} \mathrm{Co}\right)$ na manutenção da qualidade físico-química, microbiológica e sensorial de cortes de coxa e filé de peito de frango acondicionado em diferentes sistemas de embalagens. PhD Thesis, Food Engineering Faculty, UNICAMP, Campinas, SP.

Nam, K. C.; Ahn, D. U. (2002), Carbon monoxideheme pigment complexes are responsible for the pink color in irradiated raw Turkey breast meat. Meat Science, 61, 25-33.

Nanke, K. E.; Sebranek, J. G.; Olson; D. G. (1998), Color Characteristics of Irradiated Vacuum-Packaged Pork, Beef, and Turkey. J Food Sci, 63 (6), 10011006.

Pelczar Jr. M. J.; Chan, E. C. S.; Krieg, Noel R. (1997), Microbiologia: conceitos e aplicações. 2.ed. v. 2, Makron Books, São Paulo.
Pinto, D. C. C.; Mano, S. B.; Vital, H. C.; Oliveira, L. A. T.; Tello, M.V. P.; Pombo, C. R.(2005), Avaliação da irradiação gama em peitos de frangos refrigerados monitorados pela contagem de bactérias heterotróficas aeróbias mesófilas viáveis e $\mathrm{pH}$. R Bras Ci Vet, 12, (1/3), 37-41.

Roberts, T.; Weese, J. (2006), Food Irradiation. 1995. Available at: http://www.aces.edu/pubs/docs/H/HE0727/. Acessed 10 jun 2006

Samelis, J.; Kakouri, A.; Savvaidis, I. N.; Riganakos, K.; Kontominas, M. G. (2005), Use of ionizing radiation doses of 2 and $4 \mathrm{kGy}$ to control Listeria spp. and Escherichia coli O157:H7 on frozen meat trimmings used for dry fermented sausage production. Meat Sci, 70, 189-195.

Spoto, M. H.; Gallo, C. R.; Alcarde, A. R.; Gurgel, M, S, A.; Blumer, L.; Walder, J. M. M.; Domarco, R. E. (2000), Gamma irradiation in the control of pathogenic bacteria in refrigerated ground chicken meat. Sci Agricola, 57 (3), 389-394.

Souza, A. R. M.; Arthur, V.; Canniatti-Brazaca, S. G. (2007), Alterações provocadas pela irradiação e armazenamento nos teores de ferro heme em carne de frango. Ciênc Tecnol Aliment, 27 (2), 303-306.

Stone, H.; Sidel, J.L. (1998), Quantitative descriptive analysis: developments, applications, and the future. Food Technology, 5 (8), 48-52.

Toledo, T. C. F.; Canniatti-Brazaca, S. G.; Spoto, M. H. F.; Arthur, V. (2005), Sensory Evaluation of Chicken Breast Under Gamma Irradiation at Commercial Doses. J Food Sci, 70 (1), 8-12.

Thayer, D.W. (1995), Use of irradiation to kill enteric pathogens on meat and poultry. J Food Safety, 15, 181-192.

Trivedi, S.; Reynolds, A. E.; Resurreccion, A. V. A; Chen, J. (2007), Effect of electron beam irradiation on the safety of diced chicken meat and turkey frankfurters. Food Protection Trends, 27 (10), 749753.

The poultry Site. (2010). Chicken Meat to Top 81MT This Year. Available from: http://www.thepoultrysite.com/articles/1605/chickenmeat-to-top-81 mt-this-year. Accessed jan 2010.

Trajković-Pavlović, L. B.; Popović, M.B.; Novaković, B. D.; Gusman-Pasterko, V. P.; Jevtić, M. R.; Mirilov, J. M. (2007), Occurrence of Campylobacter, Salmonella, Yersinia Enterocolitica and Listeria Monocytogenes in some retail food products in Novi Sad. Cent Eur J Public Health, 15 (4): 167-171.

Vital, H. C.; Freire Júnior, M. (2008), A irradiação de alimentos In: Rosenthal, A. Tecnologia de Alimentos e Inovação: Tendências e Perspectivas. 1 ed. cap. 11. Embrapa Informação Tecnológica, Brasília, DF, pp.1193.

Received: December 16, 2009; Revised: November 26, 2010; Accepted: March 11, 2011. 